\title{
Alternatif Model Partisipatif Didalam Pemberdayaan Konsumen Cerdas Di Desa Gondangrejo, Kecamatan Windusari, Kabupaten Magelang
}

\author{
Rani Pajrin ${ }^{*}$, RR Yunita Puspandari ${ }^{2}$, Fathiya Nabila ${ }^{3}$ \\ ${ }^{1,2,3}$ Program Studi Hukum, Universitas Tidar \\ Email: ${ }^{1}$ ranipajrin@untidar.ac.id, ${ }^{2}$ yunitapuspa@untidar.ac.id, ${ }^{3}$ fathiyanabila128@ gmail.com
}

\section{INFORMASI ARTIKEL}

\section{Data artikel:}

Naskah masuk, 7 Oktober 2020

Direvisi,13 Januari 2021

Diterima, 26 Januari 2021

\section{Kata Kunci:}

Empowerment, Consumer rights, Smart consumer, Participation

\begin{abstract}
ABSTRAK
Abstract- Consumers' awareness in Indonesia in fighting for consumer rights is still relatively low, which can be seen from the Consumer Empowerment Index which is still lagging behind other European countries. Community service activities carried out in Gondangrejo Village, Windusari District, Magelang Regency are carried out by providing socialization and education about the importance of being a smart consumer who is aware of the rights and obligations of consumers. Rights and obligations are regulated in Law Number 8 of 1999 concerning Consumer Protection. The method used in this activity is a Participatory Alternative Model which uses Environmental Scanning, through the author's method of building the ability to view programs on an ongoing basis through mapping of related stakeholders. The purpose of this service activity is the participation of the community as consumers so that consumers can fulfill their rights as consumers. On the other hand, the smart consumer group can increase the national consumer empowerment index.
\end{abstract}

Abstrak- Kesadaran konsumen di Indonesia didalam memperjuangkan hak-hak konsumen masih relatih rendah dimana terlihat dari Indeks Keberdayaan Konsumen yang masih tertinggal dengan negara negara di Eropa. Kegiatan pengabdian masyarakat yang dilakukan di Desa Gondangrejo, Kecamatan Windusari, Kabupaten Magelang dilaksanakan dengan memberikan sosialisasi dan edukasi tentang pentingnya menjadi konsumen cerdas yang sadar akan hak dan kewajiban konsumen. Hak dan kewajiban tersebut diatur dalam Undang Undang Nomor 8 Tahun 1999 tentang Perlindungan Konsumen. Metode yang digunakan dalam kegiatan ini adalam Alternatif Model Partisipatif dimana menggunakan Eviromental Scanning, melalui metode penulis membangun kemampuan melihat program secara berkelanjutan melalui pemetaan stakeholder yang berhubungan. Tujuan dari kegiatan pengabdian ini adalah adanya partisipasi 


\section{Korespondensi:}

\section{Rani Pajrin}

Program Studi Hukum, Universitas Tidar

Jl. Kapten Suparman No. 39, Potrobangsan, Magelang Utara, Kota Magelang

\section{PENDAHULUAN}

Kesadaran konsumen di Indonesia didalam memperjuangkan hak-hak konsumen masih sangat rendah. Bahkan Indonesia masih tertinggal jauh dari Eropa. Indeks Keberdayaan Konsumen untuk tahun 2016 baru 30,86\% dibandingkan Eropa 51\%.(kompas 2017) Konsumen seringkali pada posisi yang tidak menguntungkan dan posisi yang lemah. Salah satu faktor yang terjadi pada konsumen adalah minimnya pemahaman yang tentang hak-hak konsumen. Disisi lain para pelaku usaha tingkat pemahaman tentang kewajibanpun belum mencukupi. (Wulandari 2012) Jika dilihat dari kedua hal tersebut maka perlu adanya edukasi yang dilakukan baik pada tingkat konsumen maupun pada para pelaku usaha.

Ketidakberdayaan konsumen terhadap produk yang digunakan dapat menimbulkan beberapa dampak yang merugikan bagi konsumen. Misalnya, 26 warga keracunan makanan saat hajatan di desa windusari, kabupaten magelang. Kemudian 22 siswa SD keracunan Es Krim di Desa Krinjing, Kecamatan Kajoran, Kabupaten Magelang. (detik.com 2010) Masalah konsumen begitu kompleks dan luas baik pada sektor barang maupun jasa. Hal ini membuat banyak permaalahan permasalahan baik sosial maupun hukum. Masalah konsumen yang sering kita temui lapangan misalnya, masalah property, pinjaman uang, koperasi, dipersulit ingin melunasi pinjaman bank, kartu kredit, dan masih banyak lagi. Pada era pasar bebas seperti saat ini konsumen dituntut harus cerdas dalam memilih produk.(Yani 2016) Akan tetapi tantangan bagi konsumen di era e-commerce ialah terkait layanan keuangan dalam penggunaan e-money. (Setiantoro et al. 2018)

Dari apa yang telah diuraikan maka terdapat masalah-masalah prioritas yang harus diselesaikan, diantaraya sebagai berikut:

a. Rendahnya pengetahuan masyarakat terhadap hak-hak konsumen;

b. Rendahnya tentang kesadaran, kemampuan dan kemandirian konsumen;

c. Tidak adanya kelompok-kelompok yang aktif didalam mengkaji tentang isu-isu konsumen;

d. Masih rendahnya indeks keberdayaan konsumen

e. Dari segi konsumen masih rendahnya tingkat kesadaran akan hak-hak konsumen, dari segi pelaku usaha masih rendahnya pemahaman pelaku usaha terhadap kewajiban yang harus dipenuhi dalam rangka mewujudkan hak konsumen.

Desa Gondangrejo, Kecamatan Windusari, Kabupaten Magelang menjadi pilot project didalam pemberdayaan konsumen cerdas. Kegiatan ini diharapkan mampu mengedukasi kelompok kelompok potensial yang ada didesa tersebut. Desa ini termasuk sulit untuk dijangkau baik dari infrastruktur maupun jaringan internet. Hal inilah yang menjadi salah satu faktor diadakanya sosialisasi dan edukasi yang 
merupakan amanat Undang-Undang Nomor 8 Tahun 1999 tentang Perlindungan Konsumen yaitu melakukan pendidikan konsumen. Target luaran dari pengabdian ini adalah Hasil Program Kemitraan Masyarakat disebarluaskan dalam bentuk artikel dan poster, Publikasi pada media masa cetak/online/repository Perguruan Tinggi, Peningkatan tingkat kesadaran konsumen akan hak-hak konsumen, Peningkatan kapasitas masyarakat binaan sehingga menjadi konsumen yang cerdas. Konsumen cerdas tentu berfikirnya holistik dalam melakukan pembelian suatu produk. Proses pembelian sendiri dimulai dari pengenalan masalah, pencarian informasi, evaluasi alternatif, keputusan pembelian dan perilaku pasca pembelian.(yakin, fahrul: 2016)

Salah satu pertimbangan konsumen dalam membeli sebuah produk didasarkan pada kualitas atau teknologi yang terbukti dan/atau merek yang mudah diidentifikasi yang menarik bagi konsumen. (Susdarwono 2020). Untuk itu, pendidikan konsumen merupakan salah satu cara didalam meningkatkan indeks keberdayaan konsumen melalui pengabdian masyarakat "Alternatif Model Partisipatif Didalam Pemberdayaan Konsumen Cerdas Di Desa Gondangrejo, Kecamatan Windusari, Kabupaten Magelang”. Pelaksanaan pengabdian kepada masyarakat dimana kami bermitra dengan Pemerintah Desa Gondangrejo, yang kemudian dalam kegiatan sosialisasi di kelompok ibu-ibu PKK diharapkan mereka mampu menjadi leader atau campaigner di komunitas maupun dikeluarganya masing-masing. Terdapat beberapa isu yang menjadi prioritas kegian ini. Secara umumnya melakukan edukasi pada masyarakat agar menjadi konsumen yang cerdas. Secara khusus adanya pemahaman kepada masyarakat tentang Undang-Undang Nomor 8 Tahun 1999 tentang Perlindungan Konsumen, khususnya pada hak dan kewajiban sebagai konsumen. Pengetahuan dan pemahaman Undang-Undang Perlindungan Konsumen menjadi prioritas dalam kegiatan ini karena masih rendah sehingga perlu dilakukan edukasi konsumen cerdas berbasis pada partisipatif masyarakat.

Kegiatan pengabdian ini akan dilakukan secara simultan di kelompok ibu-ibu PKK di Desa Gondangrejo, karena dalam kegiatan yang dilakukan selaian menyampaikan tentang substansi dari Undang-Undang Perlindungan Konsumen juga memberikan praktik-praktik perilaku konsumen cerdas diwilayah yang lain sehingga dapat diterapkan didalam kelompok konsumen diwilayah desa tersebut. Adapun solusi dari kegiatan ini adalah terbangunya jejaring konsumen cerdas yang saling memberikan update informasi seputar isu-isu perlindungan konsumen sehingga tingkat pengetahuan mereka berkembang dan selalu mengikuti perkembangan jaman.

\section{Metode Pelaksanaan}

Pelatihan dalam rangka melakukan pendidikan konsumen cerdas dilakukan di Desa Gondangrejo, Kecamatan Windusari, Kabupaten Magelang pada hari Selasa, 11 Agustus 2020. Kebutuhan yang paling mendasar dalam pendampingan ini menggunakan community based development didalam pengembangan kelompok-kelompok konsumen cerdas. Instrumen yang digunakan harus meliputi:

a. Perencanaan

Perencanaan disini, pengusul melakukan observasi terhadap isu-isu yang saat ini penting untuk dilakukan community development yaitu dibidang pemberdayaan kelompok-kelompok konsumen cerdas.

b. Implementasi

Setelah dilakukanya pemetaan serta menentukan analisis pemberdayaan maka dilakukan implementasi program yaitu sosialisasi dan edukasi pada 
kelompok-kelompok konsumen cerdas melalui consumer awareness.

c. Evaluasi

Evaluasi dilakukan setelah adanya implementasi program, hasil dari evaluasi ini digunakan dalam meningkatkan atau memperbaiki sektor-sektor mana yang perlu diperbaiki atau di benahi.

Metode yang digunakan Alternatif Model Partisipatif didalam Pemberdayaan Konsumen Cerdas Di Desa Gondangrejo, Kecamatan Windusari, Kabupaten Magelang ini menggunakan Eviromental Scanning, metode ini bertujuan membangun kemampuan melihat program secara berkelanjutan melalui pemetaan stakeholder yang berhubungan. Terdapat 3 pendekatan yang dilakukan yaitu: (Nasdian 2014)

a. Strategic scenarios analysis

Melakukan penilaian-penilaian terhadap kelompok-kelompok konsumen dengan menempatkan konteks masa datang dalam situasi sekarang, yaitu mengambil keputusan saat ini yang berkenaan dengan massa depan.

b. Customer analysis

Customer Analysis yang dimaksud memenuhi preferensi dan kebutuhan konsumen didalam memperoleh hakhak konsumen.

c. Critical isu strategies

Metode ini untuk melihat dan menilai isu-isu jangka pendek dalam kontek hak konsumen dan kewajiban pelaku usaha.

Tabel 1. Tahapan pelaksanaan pengabdian

\begin{tabular}{|c|c|}
\hline Tahapan & Penjelasan \\
\hline Pendahuluan & $\begin{array}{lr}\text { Menentukan } & \text { tempat } \\
\text { pengabdian, waktu, kelompok } \\
\text { dengan cara mengidentifikasi } \\
\text { pihak-pihak } & \text { yang } \\
\text { berkepentingan } & \text { terhadap } \\
\text { program. } & \text { Termasuk } \\
\text { menganalisis pada hasil riset }\end{array}$ \\
\hline
\end{tabular}

\begin{tabular}{|c|c|}
\hline & $\begin{array}{l}\text { atau kajian ilmiah terhadap } \\
\text { program yang akan dilakukan }\end{array}$ \\
\hline Tahap & Melakukan \\
\hline Pertama & $\begin{array}{l}\text { permasalahan dari sosialisasi } \\
\text { yang pertama kali diberikan. }\end{array}$ \\
\hline Tahap Kedua & $\begin{array}{l}\text { Melaksanakan analisis tujuan } \\
\text { berdasarkan analisis tujuan }\end{array}$ \\
\hline Tahap Ketiga & $\begin{array}{l}\text { Melaksanakan analisis } \\
\text { alternatif berdasarkan analisis } \\
\text { tujuan yang teah dirumuskan } \\
\text { pada tahapan pendahuluan }\end{array}$ \\
\hline Tahap & Menyusun \\
\hline Keempat & $\begin{array}{l}\text { terkait berdasarkan identifikasi } \\
\text { yang telah disusun pada tahap } \\
\text { pendahuluan }\end{array}$ \\
\hline Tahap Kelima & $\begin{array}{l}\text { Menyusun matriks } \\
\text { perencanaan program } \\
\text { berdasarkan analisis alternatif } \\
\text { dan analisis pihak terkait. }\end{array}$ \\
\hline $\begin{array}{l}\text { Tahap } \\
\text { Keenam }\end{array}$ & $\begin{array}{l}\text { Menyusun rencana kegiatan } \\
\text { dan rencana tindak lanjut }\end{array}$ \\
\hline
\end{tabular}

\section{HASIL DAN PEMBAHASAN}

Kegiatan ini berlangsung pada tanggal 11 Agustus 2020. Kegiatan ini merupakan rangkaian dalam roadmap pengabdian yang akan dilakukan selama tiga tahun. Kegiatan pengabdian ini dilakukan di Desa Gondangrejo, Kecamatan Windusari, Kabupaten Magelang. Untuk lebih jelasnya dapat dilihat pada bagan dibawah ini:
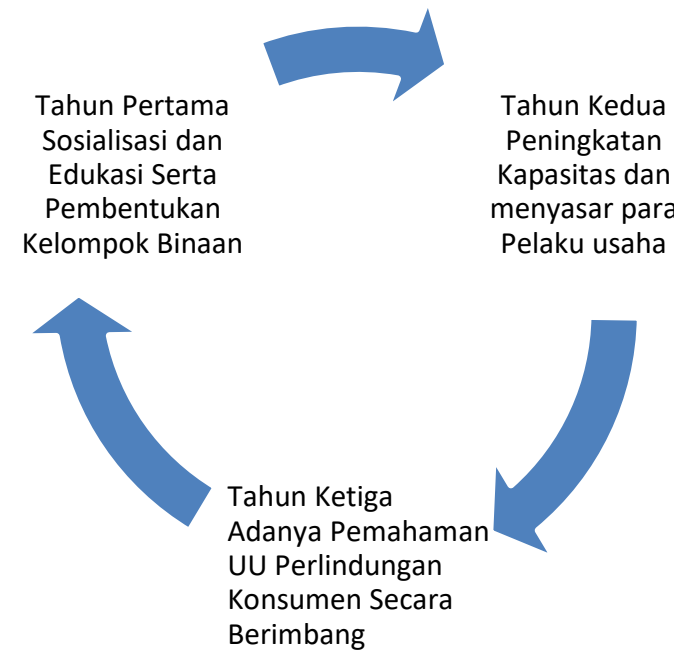

Gambar 1. Roadmap Pengabdian Masyarakat 
Roadmap pengabdian ini maka yang menjadi grand design ialah adanya pemahaman yang sama antara pelaku usaha dengan konsumen. Pelaku usaha memahami hak dan kewajibanya sedangkan konsumen memahami hak dan kewajibanya sebagai konsumen. Adapun sesuai UndangUndang Nomor 8 Tahun 1999 tentang Perlindungan Konsumen ditur sembilan hak hak konsumen diantaranya sebagai berikut:

a. Hak atas kenyamanan, keamanan, dan keselamatan dalam mengkonsumsi barang dan/ atau jasa;

b. Hak untuk memilih barang dan/atau jasa serta mendapatkan barang dan/atau jasa tersebut sesuai dengan nilai tukar dan kondisi serta jaminan yang dijanjikan;

c. Hak atas informasi yang benar, jelas, dan jujur mengenai kondisi dan jaminan barang dan/atau jasa;

d. Hak untuk didengar pendapat dan keluhannya atas barang dan/atau jasa yang digunakan;

e. Hak untuk mendapatkan advokasi, perlindungan, dan upaya penyelesaian sengketa perlindungan konsumen secara patut;

f. Hak untuk mendapat pembinaan dan pendidikan konsumen;

g. Hak untuk diperlakukan atau dilayani secara benar dan jujur serta tidak diskriminatif;

h. Hak untuk mendapatkan kompensasi, ganti rugi dan/atau penggantian, apabila barang dan/atau jasa yang diterima tidak sesuai dengan perjanjian atau tidak sebagaimana mestinya;

i. Hak-hak yang diatur dalam ketentuan peraturan perundang-undangan lainnya.

Kesembilan hak konsumen ini menjadi dasar sebagai pendidikan konsumen cerdas melalui metode Alternatif Model Partisipatif. Metode ini mengharuskan peserta berpartisipasi secara aktif tidak hanya dalam pelatihan atau sosialisasi tetapi juga dalam mempraktikanya sebagai konsumen cerdas. Untuk membekali konsumen cerdas maka, penulis menyampaikan materi - materi sebagai berikut:

Materi pertama, penulis menyampaikan tentang masalah - masalah yang dihadapi oleh konsumen baik konsumen barang maupun jasa. Penulis menyajikan data secara riil tentang kasus konsumen mulai dari rumah dilelang oleng bank, motor atau mobil ditarik oleh lembaga pembiayaan sampai kasus kerancunan produk makanan tertentu. Dari berbagai masalah tersebut penulis menyampaikan masih rendahnya pemahaman konsumen didalam memahami tentang hak-hak konsumen. Maka dari itu, konsumen perlu tahu dan faham tentang perlindungan konsumen secara preventif maupun perlindungan hukum secara represif. Salah satu bentuk perlindungan hukum secara preventif adalah adanya pendidikan konsumen cerdas. Selain itu tentu perlu adanya pembinaan kebijakan peningkatan mutu dengan adanya standarisasi produk yang akan digunakan oleh konsumen. (Mansyur and Rahman 2016) perlindungan huum secara preventif juga dilakukan oleh kepoliasian berkaitan dengan peredaran makananan kadalursa yaitu melakukan pembinaan baik kepada pelaku usaha maupun kepada konsumen.(Tampubolon, wahyu 2020)

Sebagai dasar pengetahuan tentang konsumen maka perlu dipahami pengertian konsumen, yang dimaksud konsumen ialah setiap orang pemakai barang dan/atau jasa yang tersedia dalam masyarakat, baik bagi kepentingan diri sendiri, keluarga, orang lain, maupun makhluk hidup lain dan tidak untuk diperdagangkan. Pengertian ini menjadi dasar tentang pemahaman tentang konsumen cerdas.

Materi kedua, menyampaikan tentang menjadi konsumen cerdas dibidang jasa. Dari hasil wawancara yang dilakukan, hampir seluruh peserta pelatihan merupakan konsumen jasa keuangan baik yang memiliki tabungan atau memiliki pinjaman di bank. Selain mengedukasi melalui ceramah, diskusi serta memberikan 
contoh kasus yang nyata pada sesi ini banyak peserta yang antusias didalam pelaksanaan kegiatan. Selain memberikan pemahaman baik secara teoritis yang berbasis pada Undang-Undang Perlindungan Konsumen, tim menyampaikan terkait hukum acara perdata khususnya hukum beracara di Pengadilan, BPSK (Badan Penyelesaian Sengket Konsumen) maupun LPKSM (Lembaga Perlindungan Konsumen Swadaya Masyarakat). Salah satu sengketa bisnis adalah sengketa konsumen.(Lutfi et al. 1970) Untuk itu sebagai konsumen tentu perlu tahu dan faham tentang bagaimana cara menyelesaikan sengketa konsumen.

Dalam kegiatan ini dihadiri sebanyak 25 peserta dimana terdiri dari perangkat desa dan tim penggerak pkk. Kami melihat kedua unsur ini memiliki peranan didalam melakukan edukasi secara luas dimasyarakat. Disisi lain perangkat desa merupakan pembuat kebijakan ditingkat desa sedangkan tim penggerak pkk merupakan komunitas potensial sebagai penggerak perubahan menuju konsumen cerdas. Sebelum acara dimulai setiap peserta diwajibkan mengisi pretest dan setelah selesai peserta mengisi post test. Dari hasil pretest dan postest dapat terlihat perubahan pemahaman yang terjadi dimana sebelumnya tidak tahu menjadi tahu dan faham tentang hak dan kewajiban sebagai konsumen. Untuk lebih jelas dapat dilihat pada grafik dibawah ini:



Gambar 2. Grafik Pretest

Sumber : data saat kegiatan sosialisasi dan edukasi dilakukan.
Grafik Pretest sebelum kegiatan dilakukan. Dari grafik ini dapat dilihat bahwa tingkat pemahan tentang hak konsumen masih rendah. Sedangkan tingkat pemahan kewajiban sebagai konsumen cukup tinggi. Sedangkan pengetahuan tentang lembaga perlindungan konsumen masih rendah.

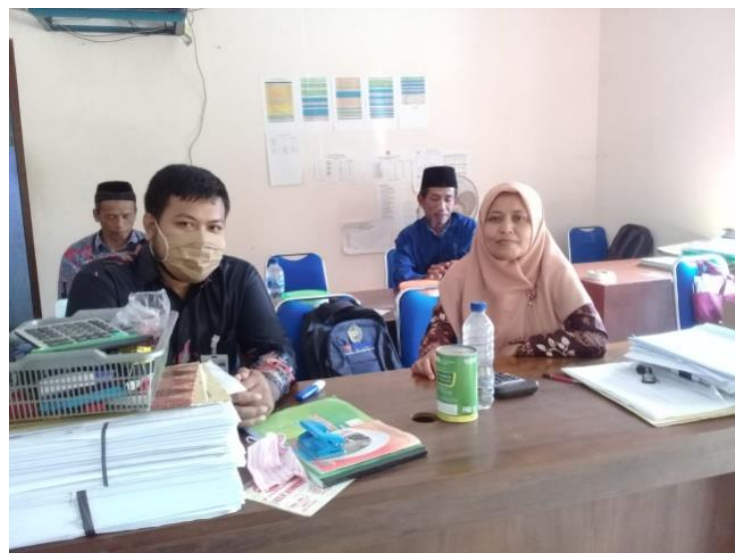

Gambar 3. Berkoodinasi denga Perangkat Desa, Desa Gondangrejo.

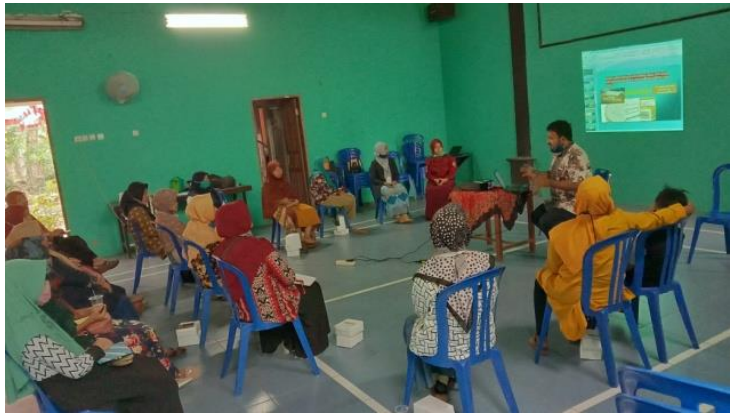

Gambar 4. Pembicara pertama menyampaikan materi tentang hak dan kewajiban sebagai konsumen.



Gambar 5. Pembicara kedua menyampaikan kasus kasus tentang sengketa konsumen dan cara menyelesaikan sengketa baik secara litigasi maupun non litigasi. 


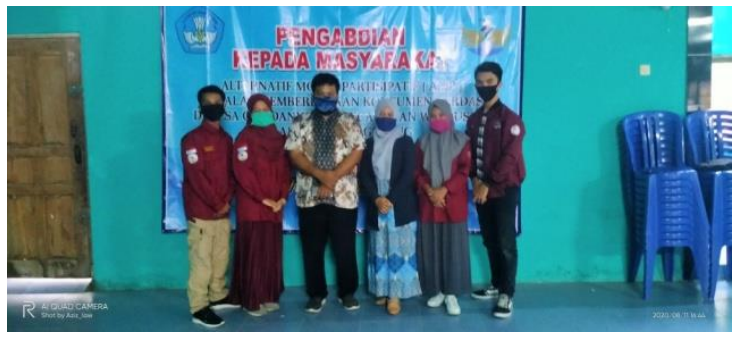

Gambar 6. Tim pengabdian kepada masyarakat yang terdiri dari Dosen dan Mahasiswa Program Studi Hukum, Universitas Tidar.

\section{KESIMPULAN}

Setelah dilaksanakan pendidikan konsumen cerdas bagi ibu-ibu tim penggerak pkk Desa Gondangrejo, Kecamtan Windusari, Kabupaten Magelang melalui metode alternatif model partisipatif tingkat kepedulian dan pemahaman tentang isu-isu konsumen menjadi meningkat. Pemahaman dan pengetahuan tentang hak dan kewajiban sebagai konsumen dalam berbasis pada Undang-Undang Nomor 8 Tahun 1999 tentang Perlindungan Konsumen.

\section{UCAPAN TERIMA KASIH}

Terima kasih kami sampaikan kepada pimpinan Lembaga Penelitian dan Pengabdian Masyarakat Penjaminan Mutu Pendidikan (LPPM PMP) Universitas Tidar yang telah memberikan kepercayaan didalam mengelola dana DIPA Pengabdian Masyarakat. Kemudian, tidak lupa kami sampaikan terima kasih kepada Perangkat Desa Desa Gondangrejo dan Tim Penggerak PKK atas kesediaan kerjasama dan terlaksananya Program Kemitraan Masyarakat ini.

\section{DAFTAR PUSTAKA}

detik.com. 2010. "22 Siswa Keracunan Es Krim.” Detiknews. Retrieved (https://news.detik.com/berita/1344298/2 2-siswa-sd-di-magelang-keracunan-es- krim?881103605=).

kompas. 2017. "Konsumen Di Indonesia Dinilai Belum Berdaya." Https://Ekonomi.Kompas.Com/Read/201 7/09/19/050000826/Konsumen-DiIndonesia-Dinilai-Belum-Berdaya.

Lutfi, Chairul, A. Latar Belakang, Bidang Analisis, and Ekonomi Atas. 1970. "Ekonomic Analysis of Law." 8(2):1-29.

Mansyur, Ali, and Irsan Rahman. 2016. "Penegakan Hukum Perlindungan Konsumen Sebagai Upaya Peningkatan Mutu Produksi Nasional." Jurnal Pembaharuan Hukum 2(1):1.

Nasdian, Fredian Tonny. 2014. Pengembangan Masyarakat. Jakarta: Yayaysan Pustaka Obor Indonesia.

Pasar, D. I., and Pagi Samarinda. n.d. "Jurnal Perilaku Konsumen Dalam Berbelanja Pakaian Wanita Di Pasar Pagi Samarinda."

Setiantoro, Arfian, Fayreizha Destika Putri, Anisah Novitarani, and Rinitami Njatrijani. 2018. "Urgensi Perlindungan Hukum Konsumen Dan Penyelesaian Sengketa E-Commerce Di Era Masyarakat Ekonomi Asean." Jurnal Rechts Vinding: Media Pembinaan Hukum Nasional $7(1): 1$.

Susdarwono, Endro Tri. 2020. "Research and Development (R \& D) Sebagai Pilar Utama Dalam Membangun Ekonomi Industri Pertahanan Indonesia." Madani : Indonesian Journal of Civil Society 2(2):59.

Tahun, Nomor, and Tentang Perlindungan. 2020. "Wahyu Simon Tampubolon P.ISSN Nomor 2337-7216, E ISSN Nomor 2620-6625." 08(01).

Wulandari, Chandra Dewi Puspitasari dan Puji. 2012. "Peningkatan Kesadaran Hak-Hak Konsumen Produk Pangan Sebagai Upaya Mewujudkan Kemandirian Konsumen Di Kabupaten Bantul.” LUMBUNG PUSTAKA UNY.

Yani, Ahmad. 2016. "Label Halal Dan Konsumen Cerdas Dalam Perdagangan Pasar Bebas.” Jurnal Geografi Gea 7(2). 